\title{
Integrin Alpha-9
}

National Cancer Institute

\section{Source}

National Cancer Institute. Integrin Alpha-9. NCI Thesaurus. Code C150272.

Integ rin alpha-9 (1035 aa, $114 \mathrm{kDa}$ ) is encoded by the human IT GA9 gene. This protein is involved in cell-matrix binding and cell adhesion-dependent signaling. 